\title{
Global History and Latin American History: A Comment
}

\section{Gustavo L. Paz}

Universidad Nacional de Tres de Febrero Instituto Ravignani/UBA/ Conicet, Buenos Aires, Argentina

glpaz2@yahoo.com

Abstract: Based on Scales of Global History dossier, this article criticizes the silences of Global History in terms of Latin American history, and reflects upon the question of how to include this history on that approach.

Keywords: Latin America; Global History.

Three of the six papers included in the dossier on Global History published in this issue of Almanack are related to Latin America. In his article on the settlement of a Mennonite community in Paraguay in the first decades of the twentieth century, Benjamin Goossen argues that their establishment in the Chaco area derives from the Mennonites' desire to retreat to an isolated region as well as from a discourse related to building a "state within a state" brought from their original settlements in North America and Eastern Europe. Two other articles deal with Latin American issues somewhat more loosely. Pepjin Brandon argues successfully that the anti-slavery push in the Netherlands was curtailed by a conservative lobby in Parliament which managed to stop any initiative towards abolition of slavery at the turn of the eighteenth century. While surrendering to British pressure to end the slave trade, the conservatives took measures as to ensure that slavery continued being the organizing labor system in the Dutch colonies, which included the sugar-producing islands of the Caribbean. Finally, Amar Farooqui's paper on the nature 
and extension of the Portuguese opium trade between India and China in the middle of the nineteenth century suggests that there was a "Portuguese global world" based on circulation of goods and people that included also Brazil.

This issue of Almanack seems to be rather exceptional in publishing papers dealing with Latin American history in a global context. Up to now, the region has not figured prominently in Global History books and journals. This neglect reflects a mutual disconnection between the fields of Latin American and Global History. Most global historians seem to be at a loss when dealing with Latin America as a region participating in global historical processes. At the same time, Latin-American historians have been slow in linking their research agendas to the emerging study of Global History. Why have Latin American History and Global History not been engaged in a more fruitful dialogue?

A recent article by Matthew Brown appeared in the Journal of Global History gives clues to solve this conundrum. ${ }^{1}$ He points out that the two leading journals in the field have published a very small number of articles on Latin America in global context. According to Brown, only $6.7 \%$ of the articles appeared in the Journal of World History deal with Latin America, and most of them focus on the colonial period between the sixteenth and the eighteenth centuries. The Journal of Global History fares only a little bit better: $9.5 \%$ of the articles published in this journal deal with Latin America, but in this case they lack a topical pattern or a common theme. ${ }^{2}$ If we turn our attention to the major recent books on global history the outcome is no better. A look at C.A Bayly's The Birth of the Modern World bibliography attests to that. ${ }^{3}$ Out of a reading list numbering some 500 books, only 11 deal with Latin America, and just one of them is in Spanish. In comparison, Bayly cites 40 books on Africa. (This is less than $10 \%$ of the total number of books, but Latin America is only $2 \%$ !.) Latin America fares somewhat better in Jurgen Osterhammel's The Transformation of the World. ${ }^{4}$ Out of a massive reading list of slightly over 2,500

\footnotetext{
${ }^{1}$ BROWN, M atthew. The Global History of Latin America. Journal of Global History, n. 10, p. 365-386, 2015.

2 BROWN, Matthew, Op. cit., p. 370.

${ }^{3}$ BAYLY, C. A. The Birth of the Modern World, 1780-1914. Oxford: Blackwell, 2004. (Spanish translation: El nacimiento del mundo moderno, 1780-1914. Madrid: Siglo XXI, 2010).

${ }^{4}$ OSTERHAM MEL, Jürgen. The Transformation of the World: A Global History of the Nineteenth Century. Princeton: Princeton University Press, 2014 (Spanish translation: historia global del siglo XIX. Barcelona: Crítica, 2015). La transformación del mundo: una
} 
entries the author cites 93 books on Latin America which make up less than $4 \%$ of the total. (Many of these books are written by Latin American historians, a few of them are in Spanish). In comparison, Africa is even less represented in Osterhammel's book: it comprises only 70 titles, which makes up less than $3 \%$ of the total. What do these rough figures show? Mainly that these two historiographies, Latin American and Global, talk to each other only sporadically, if they do at all.

What are the reasons for this disconnection? First, there is a disparity of agendas and topics between both fields of history. As Brown puts it in his article,

The central questions asked by global historians have often been about EastWest connections and comparisons. Latin America's problematic identification with 'the West' complicates this binary force.

First, there is the question of Latin America's proximity to the West. Global historians usually portray Latin America as a periphery of the most dynamic regions engaged in global interactions, namely of Western Europe and North America. These historians seem to consider Latin America only as a passive recipient of the changes experimented and exported from these two core areas. Latin America is perhaps the closest "periphery" to the Western World. Its territories and peoples were conquered and colonized by European powers (namely Spain and Portugal) in the Early Modern period. Also, the region participated actively of the sweeping changes brought about by the Era of Revolutions at the turn of the eighteenth century, a process that led to the formation of newly independent polities that organized themselves as republics. ${ }^{6}$ As these historical processes connect Latin America very closely to the Western world, many historians of Latin America have begun to place the region in the context of Atlantic history which has been widely accepted (and to a certain degree fostered) by European and North American historians working within this historiographical paradigm. ${ }^{7}$ But so far, global historians

\footnotetext{
${ }^{5}$ BROWN, Matthew, Op. cit., p. 369.

${ }^{6}$ To one historian of Latin America, the region was "the other West (Marcello Carmagnani), to a sociologist was the "extreme West" (Alain Rouquié), see: CARMAGNANI, Marcello. El otro occidente: América Latina desde la invasión europea hasta la globalización. México: Fondo de Cultura Económica, 2004; and ROUQUIÉ, Alain. América Latina: Introducción al extremo occidente. México: Siglo XXI, 1986.

${ }^{7}$ See for instance: BAILYN, Bernard. Atlantic History: Concepts and Contours. Cambridge (Mass.): Harvard University Press, 2005.
} 
have been reluctant to give more room to Latin America in their studies. After all, if Latin America is so close a periphery to the West, what features of its history are "peculiar" to the region that would render them worth noticing so as to be included in a global context?

Second, there is the question of the historian's area of specialization. Historians specialized in one area of the world tend to delve more into the region of their expertise when dealing with global historical topics. They tend to draw examples and illustrations from cases close to their field of expertise. Most of the historians who write history with a global perspective are experts on Europe and European imperialism, Southeast Asia (mostly China), India, and to a lesser extent, North America. Whenever they branch out, they tend to cover more thoroughly the areas of more recent European expansion and colonization (such as Africa and Asia) or they incorporate old, non-colonial nations such as China and Japan. ${ }^{8}$ Latin America is an area of "old colonization" (i.e. Early Modern) and in this respect it falls out of the full-fledged era of globalization starting in the nineteenth century.

Third, the language skills of the historian have to be taken into consideration. For Latin American historians writing in languages other than English, it is hard to beat the linguistic barrier that separates them from global history. Whereas most global historians write in English and most of the literature on global history is written in English, most of the scholarship on Latin America is written in Spanish and Portuguese. Translations are usually time- and money-consuming endeavors, both from English to Spanish or Portuguese and vice versa. Therefore, unless the global historian (whatever his or her native language) is an expert on Latin America and therefore is familiarized with the work of historians from Latin America, or the global historian is not an expert in Latin American history but has the language skills to read those works in their original language, the scholarship of Latin American historians remains largely unnoticed by global history practitioners.

\footnotetext{
${ }^{8} \mathrm{I}$ am thinking here, for instance, about C. A. Bayly, an expert in India and British Imperial expansion who branches out to incorporate China, Japan, and the Middle East in his global account, and of Jurgen Osterhammel, an expert in Chinese history, who covers most areas of the world in his massive book, but concentrates heavily on India and the Arab world. A partial exception to this rule of global history writing is the recent book by the distinguished Spanish historian FUSI, Juan Pablo. Breve historia del mundo: de la Edad Media hasta hoy. Barcelona: Galaxia Gutenberg, 2016. Though heavily centered on Europe, Fusi's narrative gives ample room to Latin America.
} 
Finally, I would like to consider the conditions of scholarly work in Latin America that can account for the slow adoption of the global perspective by historians of the area. In his article Brown contends that Latin American historians' reluctance to accept global history as a legitimate interpretive paradigm is closely related to the fact that they continue working within a national historical framew ork. In his words,

The slow disengagement from the "national" might be seen as a symptomatic of the inability of the historical discipline there to deal with the pressures of a globalizing world, or the resilience of the national paradigm many years after this was made obsolete elsewhere. ${ }^{9}$

I would like to dispute his assertions. M ost professional Latin American historians are very aware of the obsolescence of the national paradigm applied to historical analysis and are trying to break away from it. Never before have historians from Latin America produced scholarship that questions the national paradigm, despite the difficulties in getting enough funding to do research abroad and to access to libraries and databases suitable for comparative work. Despite these difficulties, a growing number of historians have started to produce works that transcend their nations' borders. To give examples drawn from a period I am familiar with, Latin American historians working on the Era of Revolutions (1770's-1830's) have been writing against the nationalist version of their countries' independences, placing their studies within a comparative context, being it Latin American, Iberian or Atlantic. ${ }^{10}$ Other Latin American historians have written fine comparative histories encompassing more than one country or have tackled comparative themes that range from political to economic to social history. ${ }^{11}$

These studies may not perhaps fit into the global history paradigm as their range is confined within the comparison of two cases or to the opposite (i.e. European and

\footnotetext{
${ }^{9}$ BROWN, Matthew, Op. cit., p. 374.

${ }^{10} \mathrm{~A}$ few examples of this recent comparative scholarship are: PIMENTA, João Paulo. Estado e nação no fim dos impérios ibéricos no Prata (1808-1828). São Paulo: Hucitec/FAPESP, 2002; PRADO, Fabrício. Edge of Empire: Atlantic Networks and Revolution in Bourbon Rio de la Plata. Berkeley: University of California Press, 2015; and BORUCKI, Alex. From Shipmates to Soldiers: Emerging Black Identities in the Rio de la Plata. Albuquerque: University of New Mexico Press, 2015.

${ }^{11}$ See for instance: PINTO VALLEJOS, Julio; PALMA ALVARADO, Daniel; DONOSO FRITZ, Karen; PIZARRO LARREA, Roberto. El orden y el bajo pueblo: Los regímenes de Portales y Rosas frente al mundo popular 18291852. Santiago: LOM Ediciones, 2015; and FAUSTO, Boris; DEVOTO, Fernando. Argentina-Brasil (1850-2000): un ensayo de historia comparada. Buenos Aires: Sudamericana, 2008.
} 
American) shores of the Atlantic Ocean. But the trend towards widening the horizons of Latin American history is picking up, albeit slowly. Thanks to the development of digital technology Latin American historians find it easier now to get access to journal articles, books and sources that facilitate comparisons. Also, some institutions deeply committed to developing global history have launched projects that include Latin American historians as participants engaged in comparative research. ${ }^{12}$

Latin American historians have begun to look at the world at large to understand their own history. In time, global historians ought to start looking at Latin America as a significant part of the globe in its own right.

Data de recebimento do artigo: 12/11/2016

Data de aprovação do artigo: 30/11/2016

\section{Bibliography}

BROWN, Matthew. The Global History of Latin America. Journal of Global History, n. 10, p. 365-386, 2015.

BAILYN, Bernard. Atlantic History: Concepts and Contours. Cambridge (Mass.): Harvard University Press, 2005.

BAYLY, C. A. The Birth of the Modern World, 1780-1914. Oxford: Blackwell, 2004.

. El nacimiento del mundo moderno, 1780-1914. Madrid: Siglo XXI, 2010.

BORUCKI, Alex. From Shipmates to Soldiers: Emerging Black Identities in the Rio de la Plata. Albuquerque: University of New Mexico Press, 2015.

CARM AGNANI, M arcello. El otro occidente: América Latina desde la invasión europea hasta la globalización. México: Fondo de Cultura Económica, 2004.

FAUSTO, Boris; DEVOTO, Fernando. Argentina-Brasil (1850-2000): un ensayo de historia comparada. Buenos Aires: Sudamericana, 2008.

\footnotetext{
12 I am thinking of LabM undi-USP established at the University of São Paulo, which is a partner institution of the Weatherhead Initiative on Global History at Harvard University.
} 
FUSI, Juan Pablo. Breve historia del mundo: de la Edad Media hasta hoy. Barcelona: Galaxia Gutenberg, 2016

OSTERHAMMEL, Jürgen. The Transformation of the World: A Global History of the Nineteenth Century. Princeton: Princeton University Press, 2014.

. La transformación del mundo: una historia global del siglo XIX. Barcelona: Crítica, 2015.

PIM ENTA, João Paulo. Estado e nação no fim dos impérios ibéricos no Prata (1808-1828). São Paulo: Hucitec/FAPESP, 2002.

PINTO VALlEJOS, Julio; PALMA ALVARADO, Daniel; DONOSO FRITZ, Karen; PIZARRO LARREA, Roberto. El orden y el bajo pueblo: los regímenes de Portales y Rosas frente al mundo popular 1829-1852. Santiago: LOM Ediciones, 2015.

PRADO, Fabrício. Edge of Empire: Atlantic Networks and Revolution in Bourbon Rio de la Plata. Berkeley: University of California Press, 2015.

ROUQUIÉ, Alain. América Latina: Introducción al extremo occidente. México: Siglo XXI, 1986. 